\title{
CHANGES IN THE GEOGRAPHIES OF WORK AND HOME - THE ERC WORKANDHOME PROJECT
}

\section{Darja Reuschke, University of St. Andrews, UK}

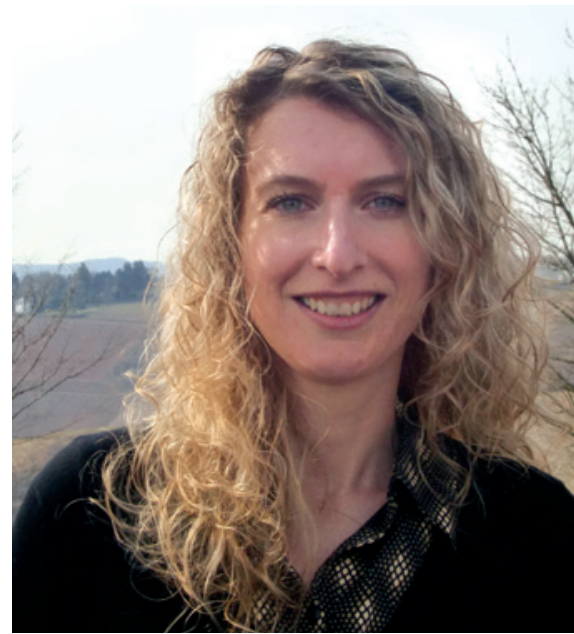

\section{Background}

Digitalisation and globalisation of production have brought about the 'third industrial revolution' (Rifkin, 2011), after the 'first industrial revolution' was set-off in Britain in the late 18 th century by the mechanisation of the textile industry and the evolution of industrial mass production through Ford's assembly line which has been labelled the 'second industrial revolution'. Some scholars already see the 'fourth industrial revolution' on the horizon as introduced by a new generation of flexible robots and assistance systems (Krzywdzinski et al., 2015). Sectoral and occupational restructuring are well documented in the literature as are substantial changes that European societies have faced over the past three decades in relation to work organisation, flexibilisation, deregulation, casualization, polarisation, globalisation and immigration. More recent trends include: ageing and extending working lives; 'work-life' balance; and precarious and temporary forms of employment. With respect to businesses, it is well established that small businesses have increased in significance and that ICTs and the internet are key drivers of new forms of businesses and business organisation. In particular, online businesses have emerged that sell services or goods solely or mostly through the internet, and this trend has been reinforced by the growth of project-based organisational structures, involving collaboration of knowledge workers for a certain period of time (DiDomenico et al., 2014;
Grabher 2002).

The existing literature, however, is characterised by the separation of worklife and homelife and the divorce of organisations (firms) from individual economic actors. As a consequence, home-based self-employed workers and entrepreneurs fall outside most existing research and theory-building. Economic geographers and other spatial scientists have been attracted by transnational and high-tech corporations, mostly concentrated in technology clusters while the individual as an economic actor has been largely neglected. Management and entrepreneurship studies have mainly focused on organisational issues of business ventures or, to a lesser extent, individual entrepreneurs or owner managers with growing companies while economic activity of self-employed workers or small-scale business owners have been mainly outside the scope of this research including small business research. Employment researchers in economics and sociology have been guided by a narrow, conservative focus on the 'job'. 'Non-standard' work has attracted interest since the late 1980s. However, the focus has been mainly on temporal changes of work while less attention has been paid to

Figure 1: Development of non-farm self-employment as a percentage of non-farm employment in Europe 1999-2013, in per cent

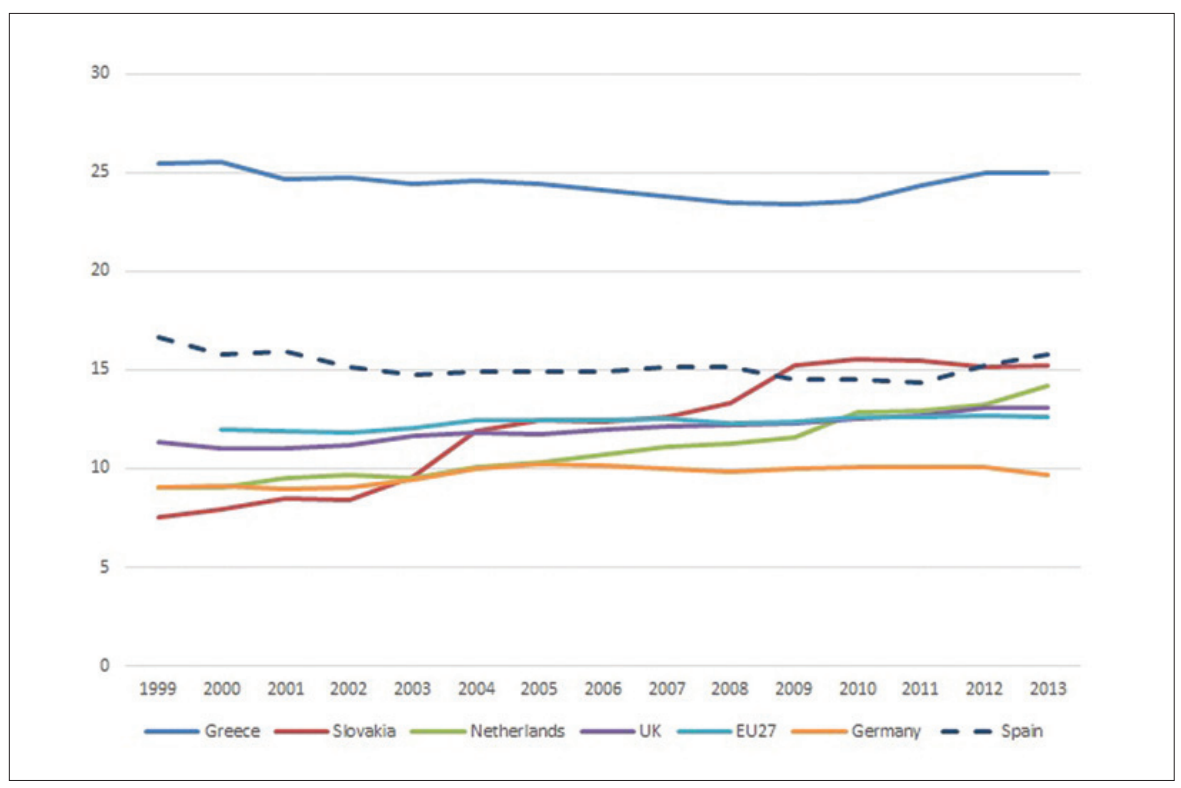

Source: Eurostat Labour Force Survey, own compilation spatial changes and the shift towards self-employment. Transport, mobility and time geography studies have explored individuals' mobility behaviour and time-space use but without paying much attention to the kind of work people are engaged with and the home as workplace. Neighbourhood and housing researchers have explored housing search behaviour and neighbourhood effects on individuals' employment outcomes but the changing work-residence relations and self-employment have also not featured in this research. of work in modern societies are related to self-employed work and this has substantially changed industrial workresidence relations. Modern economies have produced high levels of selfemployment in Europe outside the agricultural sector. Now almost $13 \%$ of non-farm workers are self-employed in the EU27 (Figure 1). The Netherlands and Slovakia are amongst the countries in Europe that have experienced the largest increases in non-farm self-employment over the past 15 years (Figure 1). Most importantly, modern self-employment outside the agricultural sector is not a recession phenomenon nor has it declined
Significant changes in the organisation 
Figure 2: Number of homeworkers in the USA, 1960-2010

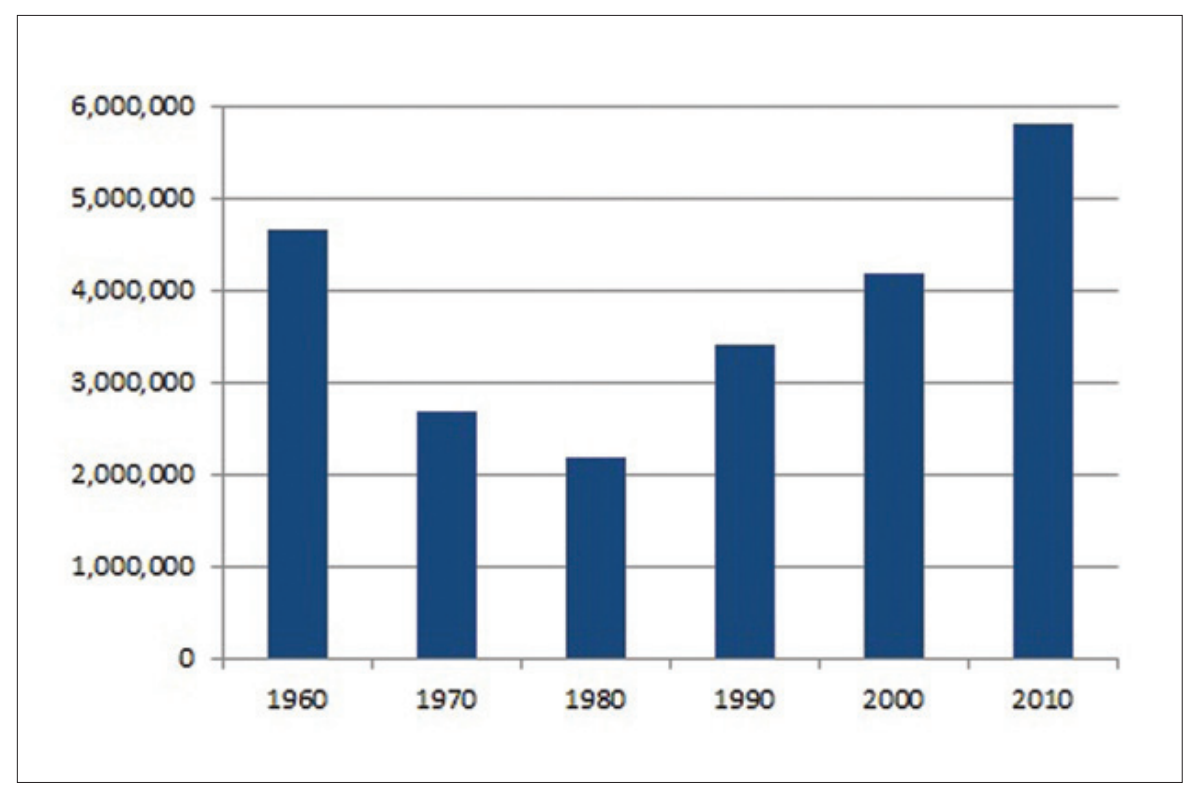

Source: Census data taken from U.S. Department of Commerce (1998) and Mateyka et al. (2012), own compilation

after the dotcom bust with Greece and Spain consistently having high rates of non-farm self-employment (Figure 1).

Self-employment has fuelled another substantial change in modern societies: the blurring of work and home. Figure 2 shows the homeworking trend in the USA. The USA is taken as an example as here a relatively long time series of homeworking, going back to 1960 , is available. Homeworking has traditionally been related to self-employed work in agriculture and therefore declined in the industrial economy. However, since deindustrialisation and the rise of a service economy, the homeworking trend has reversed with numbers of homeworkers rising constantly since the 1980's. This trend is of wider relevance. For example, the Office for National Statistics (ONS) in the UK revealed that the home worker rate is now at its highest level since the official recording began in 1998 (ONS, 2014).

The homeworking figures presented in Figure 2 include employees, the selfemployed and unpaid family members in family businesses. However, the self-employed represent the largest proportion of people working from home. For example, in the UK in 2014 almost two-thirds of homeworkers were self-employed (ONS, 2014). Thus it is surprising that the existing homeworking literature has been mostly concerned with 'teleworking' and 'telecommuting' of employees (Felstead et al. 2005; home-based self-employed workers. This percentage share ranges between five per cent and 15 per cent across the EU (Figure 3). However, we can assume that, in reality, the relevance of homebased self-employment will be higher as a lot of this type of work will occur as secondary work (cf. Figure 6) or will be informal which is not covered in these data.

The role which home-based work plays in modern economies becomes even clearer if we look at firm counts. The European economy is made up of micro firms, that is firms with zero to nine employees (Figure 4). In the UK, for example, three quarters of all firms do not have any employees. Using the same $60 \%$ home-based percentage share as above, then $45 \%$ of all firms in the UK can be expected to be home-based. This may be an underestimation as other sources mention higher estimates (e.g. Mason et al., 2011). Home-based businesses will vary in significance and characteristics across space. In cities with a strong service economy the percentage share of home-based businesses in the business population may be higher. The Scottish Government estimates that 69\% of firms in the City of Edinburgh are home-based.

Factors established in the literature to explain firm choices are largely

\section{Figure 3: Estimates of homeworking self-employed workers outside agriculture in the EU, 2013, in per cent}

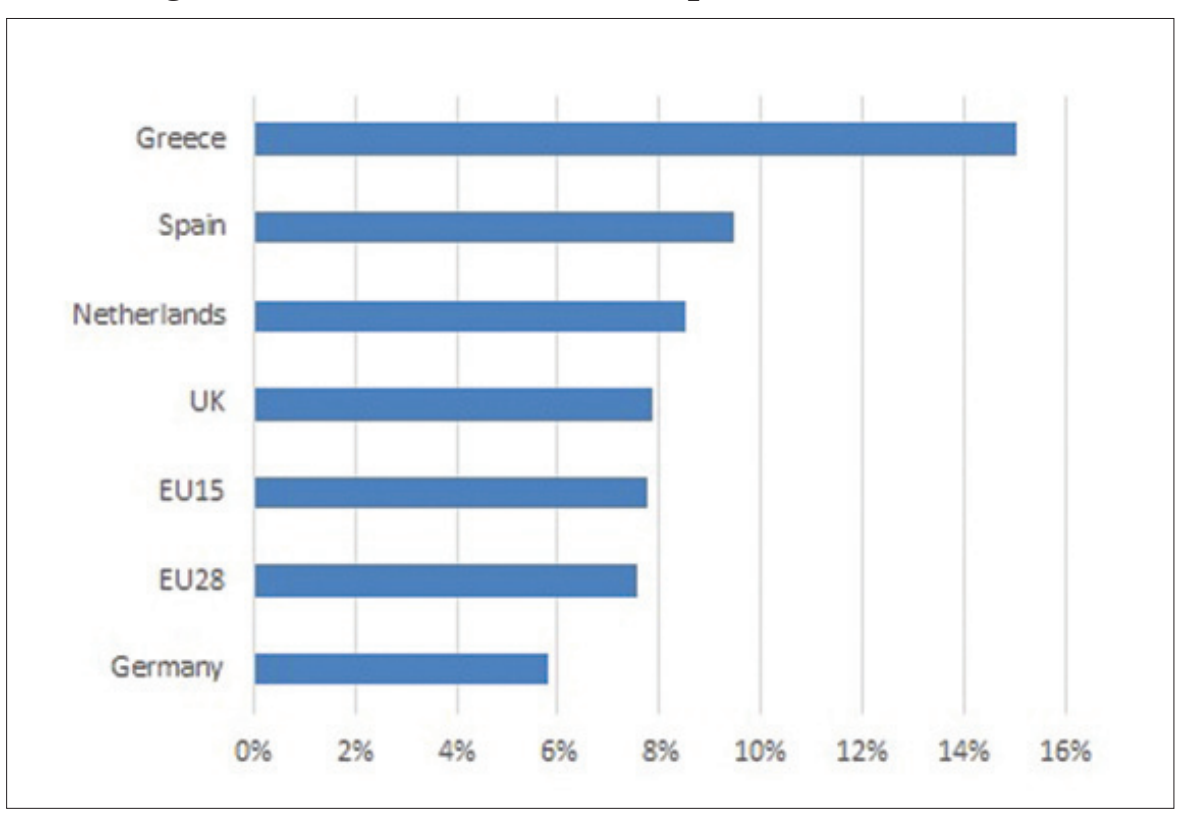

Note: It is estimated that $60 \%$ of self-employed work is home-based. This estimate was derived from the UK Labour Force Survey 2013.

Source: Eurostat Labour Force Survey, own compilation 
Figure 4: Micro firms and home-based firms, 2011 (EU) and 2013 (UK), in per cent

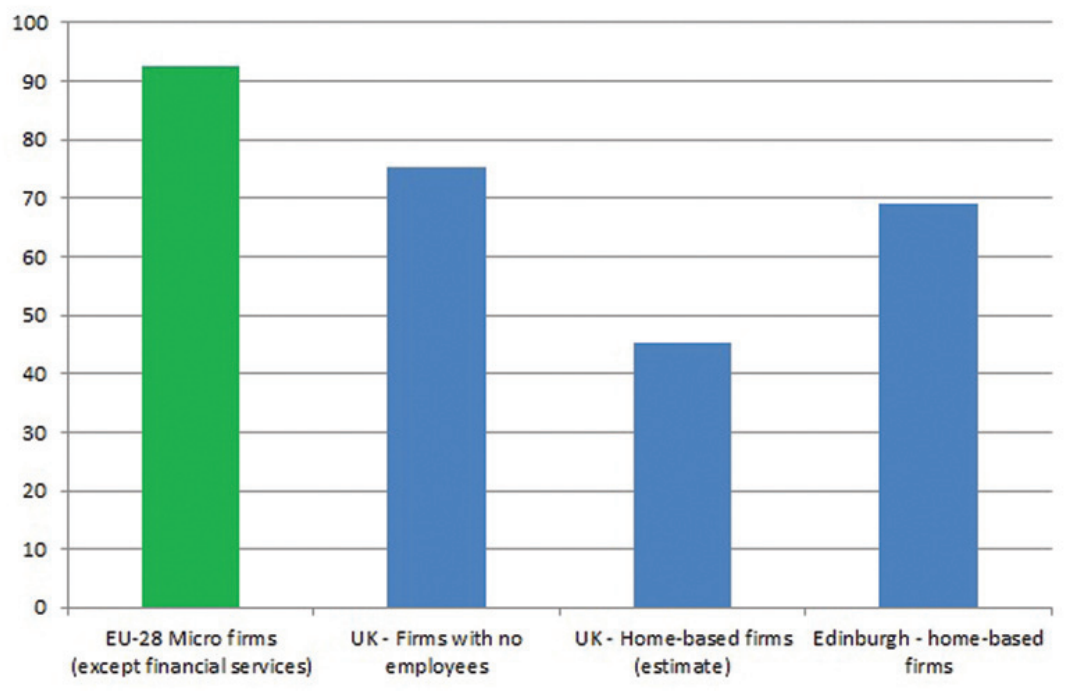

Notes: Micro firms are firms with 0-9 employees.

Source: Eurostat, BIS Business Demography, Scottish Government; own compilation

irrelevant to micro firms and homebased entrepreneurs. In our own random survey of micro firms in Edinburgh, we found that being close to the home is the third most important aspect for micro firms' locational choices, and when asked why people started-up their own business, $30 \%$ said because

Figure 5: Aspects that are relevant for micro firms

\section{What is very important?}

$1^{\text {st }}$ Broadband

$2^{\text {nd }}$ Appearance of premises

$3^{\text {rd }}$ Close to home

$7^{\text {th }}$ Local workforce

$10^{\text {th }}$ Proximity to suppliers

Why started business?

$30 \%$ work from $/$ near the home or work flexible hours

Source: own survey of 186 micro firms in Edinburgh 2013/14 of personal preferences to work from or near the home or to work flexible hours (Figure 5). This underlines the fact that something clearly has changed about how people do business and why.In order to understand modern self-employment and doing business, it is important to connect work and doing business with the business owners' domestic and household spheres. Embedding work and businesses in the home brings to the fore personal relations with family members but also neighbours and more generally people living close-by. Hence, a realm of social relations that have been the focal point in neighbourhood and housing research.

In conclusion, home-based selfemployment and businesses vividly manifest the interconnection of 'home' and 'work' and of the 'economic' and the 'social' as part of an increasingly complex society, where the boundaries between work and home domains are blurring. Moreover, if eight per cent of the workforce are home-based self-employed workers and half of all businesses are run from the home, this will affect neighbourhoods and the urban structure in ways not captured by existing economic theory and conventional urban models that are based on zones and commutes.

\section{The WORKANDHOME project}

The WORKANDHOME project investigates current fundamental changes in how people work and live and how this shapes cities through the lens of people running businesses from home. It explores the overlaps of social and economic spheres and aims to change how we understand and classify economic activity, the home, the firm, places of economic activity, labour markets and 'residential' neighbourhoods. It is the first comprehensive study on the social, economic and spatial aspects of homeworking by self-employed workers and entrepreneurs.

This five-year research project is funded by the European Research Council with an ERC Starting Grant awarded to Dr Darja Reuschke from the University of St Andrews. The ERC project started in October 2015 with partners based at the University of St Andrews (Dr Reuschke, Dr Adam Barker and Dr Jed Long), Utrecht University in the Netherlands (Prof Veronique Schutjens) and the ILS Dortmund in Germany (Andrea Wesbuer-Dittrich and Frank Osterhage).

The framework developed in WORKANDHOME puts individuals within their social household and home context at the centre and not the firm or the 'isolated' entrepreneur. The firm is conceptualised as a social entity that overlaps with the social context of the corporate actor and not as a hierarchical organisation. Economic action and social action are interconnected. This is fundamentally different to the existing organisational perspective on firms in which corporate actors are perceived to act as agents of the firm that they represent. The novel scale at which economic action will be investigated is the neighbourhood. This new paradigm will allow us to understand the wider societal impacts of micro firms and home-based self-employment and their impact on urban structure which is impossible with the existing paradigm that is restricted to growth issues and power relations within and between firms.

Empirically and theoretically, the focal point of this study is homeworking of self-employed workers and business owners that has emerged in the knowledge-based economy, under 
conditions of market deregulation and modernisation (e.g. web-based professions) in order to understand interrelations with social and economic changes and social inequalities. This will be achieved through investigating:

1. the socio-economic drivers of home-based self-employment and businesses,

2. their interlinked social and economic activities and networks,

3. their outcomes in relation to individuals and households, housing, the urban structure and neighbourhoods, and

4. their spatial and residential context.

This will be through novel combinations of social science and computational methods and data linkages.

Existing data sources are often not suitable to investigate home-based selfemployment and businesses reflecting how little data collectors and researchers have responded to current changes in work and business organisation and location. Key secondary data sources that will be used are: the Eurostat Labour Force Survey, the British Household Panel Survey, the UK Understanding Society, the German Socio-Economic Panel Study, UK Population Census data, the Study on the Social Networks of the Dutch and the Study on the Social Networks of Entrepreneurs.

Figure 6: Numbers of workers who are self-employed as secondary employment, 2000-2013, in thousands

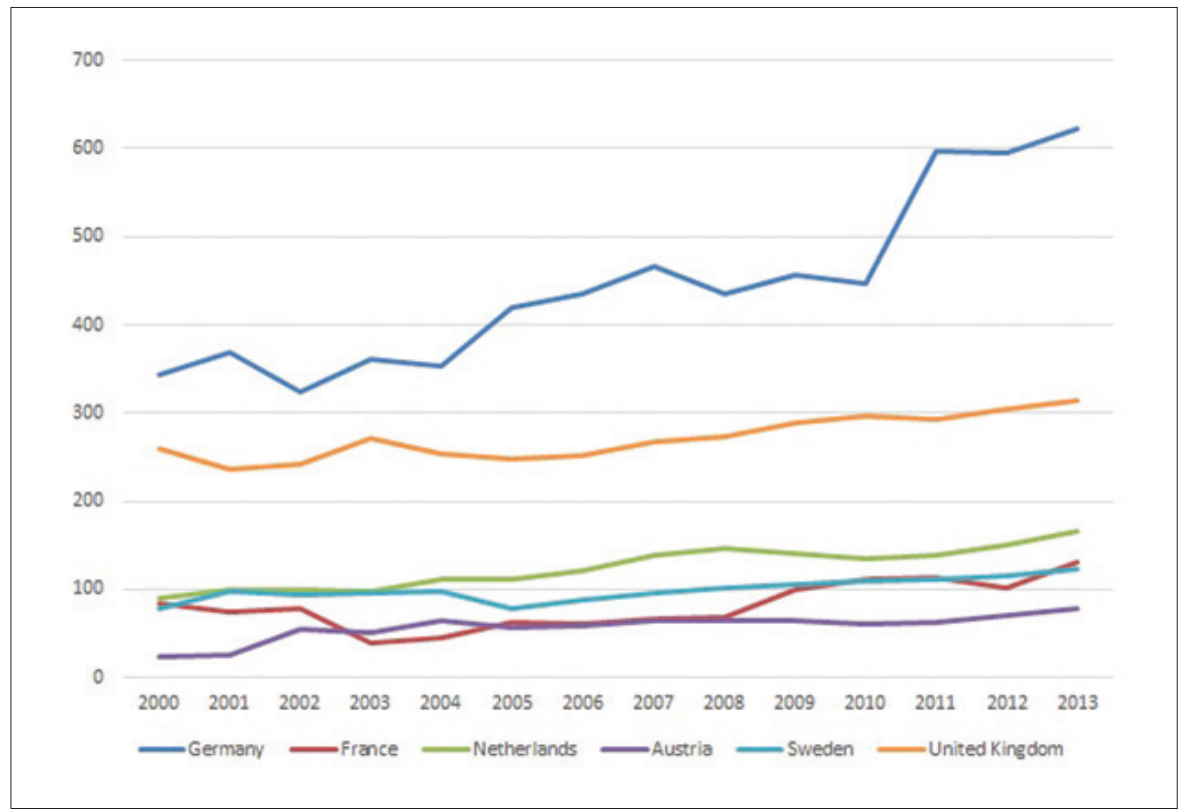

Source: Eurostat Labour Force Survey, own compilation
The geographic focus of the empirical work will be the UK, the Netherlands and Germany. The experienced tremendous rises in selfemployment and solo self-employment (i.e. with no employees) in particular. It is estimated that the proportion of home-based self-employed workers in the workforce is well above the EU average in the Netherlands (Figure 3). Interestingly, the UK and the Netherlands differ with respect to their housing system and welfare regime. So the context of this rise of selfemployment and homeworking is quite different. Self-employment is lower in Germany than the first two case study countries (Figure 1). However, selfemployment has increased in Germany particularly as secondary employment (second 'job') (Figure 6). One may assume a great importance of the home particularly for 'part-time' selfemployment (Mason and Reuschke, 2015).

We are keen to get in contact with researchers in other countries to learn more about home-based selfemployment and businesses and how to capture them beyond the UK, Germany and the Netherlands. So, if you are interested in this topic or would like to work with us, please, get in touch. UK and the Netherlands have both

\section{References}

DiDomenico, M.; Daniel, E. and Nunan, D. (2014) 'Mental mobility' in the digital age: entrepreneurs and the online homebased business," New Technology, Work and Employment, 29(3), pp. 266-81.

Felstead, A., Jewson, N. and Walters, S. (2005) Changing Places of Work, Houndsmills and New York: Palgrave Macmillan.

Grabher, G. (2002) "Cool projects, boring institutions: temporary collaboration in social contexts," Regional Studies, 36(3), pp. 205-14.

Hardill, I. and Green, A. (2003) "Remote working - altering the spatial contours of work and home in the new economy," New Technology, Work and Employment, 18, pp. 212-22.

Krzywdzinski, M., Jürgens, U. und Pfeiffer, S. (2015) „Die vierte Revolution Wandel der Produktionsarbeit im Digitalisierungszeitalter," WZB Mitteilungen Heft 149, September 2015

Mason, C. and Reuschke, D. (2015) "Home truths. The true value of home-based businesses," Glasgow, Federation of Small Businesses Scotland. http://www. fsb.org.uk/policy/rpu/scotland/assets/ home $\% 20$ truths $\% 20-\% 20$ final.pdf

Mason, C.M., Carter, S. and Tagg, S. (2011) "Invisible Businesses: The Characteristics of Home-based Businesses in the United Kingdom," Regional Studies 45, pp. 625-39.

Mateyka, P., Rapino, M. and Landivar, L. (2012) Home based workers in the US in 2010. Washington, D.C., US Department of Commerce, US Census Bureau.

Office for National Statistics (ONS) (2014) Characteristics of homeworkers. ONS, London, UK.

Rifkin, J. (2011) The Third Industrial Revolution: How Lateral Power is Transforming Energy, the Economy, and the World. Palgrave Macmillan, London et al.

U.S. Department of Commerce (1998) Increase in At-Home Workers Reverses Earlier Trend. Census Brief CENBR/98-2. U.S. Department of Commerce; Bureau of the Census, download: http://www.census.gov/ prod/3/98pubs/cenbr982.pdf

Dr. Darja Reuschke is a lecturer in the Department of Geography and Sustainable Development at the University of St Andrews, UK. She is Principal Investigator of the research project WORKANDHOME, funded by the European Research Council with an ERC Starting Grant (Grant agreement ERC-StG-2014 639403). darja.reuschke@st-andrews.ac.uk Phone: +44(0)1334-46-3902 